\title{
CA6 Gene
}

National Cancer Institute

\section{Source}

National Cancer Institute. CA6 Gene. NCI Thesaurus. Code C113531.

This gene plays a role in the reversible hydration of carbon dioxide. 